\title{
PENILAIAN GIZI SEDERHANA: ALAT PENILAIAN PRAKTIS UNTUK MENENTUKAN STATUS GIZI PASIEN RAWAT INAP DI RUMAH SAKIT
}

\author{
Ida Mardalena' ${ }^{1}$, Bambang Suprapto ${ }^{2}$, Widardo ${ }^{2}$, Bhisma Murti $^{2}$
}

\begin{abstract}
Background: Absence of effective and efficient screening tool for assessment of nutritional status have lead to high incidence of malnutrition among hospitalized patients.

Objective: To develope practical screening tool for assessing nutritional status of hospitalized patients.

Method: A simple method of nutritional assessment, called The Simple Nutritional Assessment, was compared to albumin serum as the gold standard. This study involved 50 nurses and 50 hospitalized patients in Dr. Moewardi General Hospital, Surakarta.

Result: There was significant concordance of nutritional status assessed by the Simple Nutritional Assessment and the level of albumin serum $(k=0,92)$. Sensitivity, specificity, and likelihood ratio of the Simple Nutritional Assessment compared to serum albumin were $92 \%, 67-75 \%$, and 3.8 , respectively. Internal consistence of the Simple Nutritional Assessment is high (Alpha=0.80). Average time required for doing the assessment was only 5 minutes.

Conclusion: The Simple Nutritional Assessment can be used for quick screening of nutritional status of hospitalized patients with high sensitivity and reliability.
\end{abstract}

Key words: nutritional status, hospitalized patient, screening tool, malnutrition

\section{PENDAHULUAN}

Masalah gizi di rumah sakit, seperti tingginya insiden malnutrisi energi dan protein pada pasien yang dirawat inap telah diketahui sejak lebih dari 20 tahun yang lalu $(1,2)$. Selama dirawat inap di rumah sakit, $40 \%$ pasien menjadi kurang gizi dan dua pertiga pasien mengalami kehilangan berat badan. Hasil penelitian menunjukkan bahwa kehilangan $25 \%$ berat badan berhubungan dengan keadaan pasien yang apatis, depresi, fatique dan penyembuhan luka yang lambat. Konsekuensi dari kehilangan kekuatan otot berakibat pada gangguan fungsi pernapasan, meningkatkan risiko infeksi saluran napas dan menurunnya fungsi jantung. Kerusakan fungsi imun akan meningkatkan risiko infeksi serta terjadinya komplikasi yang semuanya berdampak terhadap meningkatnya morbiditas, mortalitas dan lama rawat inap dengan konsekuensi bertambahnya biaya perawatan kesehatan. Survei pada pasien yang dirawat di rumah sakit di Inggris menemukan lebih dari $20 \%$ pasien kurang gizi $(1,2)$.

Sejak 30 tahun yang lalu diketahui bahwa di negara maju seperti Eropa dan Amerika, prevalensi malnutrisi pada pasien yang baru masuk ke rumah sakit berkisar antara $20-40 \%$ (3) dan keadaan tidak bertambah baik 20 tahun kemudian (1). Penelitian lain menemukan malnutrisi pada $40-55 \%$ pasien dewasa yang dirawat dan $22-23 \%$ di antaranya dengan malnutrisi berat (4). Ironisnya, semakin lama pasien dirawat inap di rumah sakit, status gizinya bertambah buruk. Tujuh puluh delapan persen pasien mengalami penurunan status gizi pada saat dipulangkan dari rumah sakit (1).

Pada tahun 1992 King's Fund melaporkan bahwa dengan memberikan dukungan nutrisi pada pasienpasien malnutrisi dapat menghemat dana sebesar $£ 266 \mathrm{~m}$ melalui percepatan penyembuhan dan mengurangi lama rawat inap di rumah sakit (2). Hasil studi di 15 daerah di Amerika menunjukkan bahwa pemberian dukungan terapi nutrisi dapat menghemat biaya perawatan sebesar $\$ 11.000-\$ 16.000$ pada setiap pasien setiap kali dirawat. Delapan puluh lima persen populasi dewasa yang mempunyai satu atau lebih penyakit kronis yang terlibat dalam suatu survei di Amerika telah melaporkan keuntungan yang mereka rasakan dari intervensi nutrisi (5).

Pengkajian gizi merupakan suatu tantangan karena sangatlah sulit untuk mendefinisikan malnutrisi dengan tepat. Tidak ada baku emas yang dapat digunakan untuk mengambarkan status gizi. Walaupun begitu, kombinasi dari berbagai indikator seperti antropometri, parameter biokimia, asupan makanan dan adanya faktor risiko telah direkomendasikan dan telah digunakan dalam klinik untuk membuat klasifikasi dari status gizi (4). Banyak cara yang dapat digunakan untuk melakukan penilaian status gizi tetapi belum ada cara atau alat yang paling tepat untuk menyatakan status gizi yang dapat diterima oleh semua kalangan (6).

Penelitian ini bertujuan untuk mengembangkan alat penilaian gizi sederhana untuk menentukan status gizi pasien rawat inap yang dapat digunakan oleh tim asuhan gizi di rumah sakit, terutama oleh para

\footnotetext{
Jurusan Keperawatan Poltekkes Bengkulu

${ }^{2}$ Universitas Sebelas Maret Surakarta
} 
perawat. Hasil penelitian ini diharapkan dapat digunakan untuk melakukan penapisan (screening) risiko malnutrisi pada pasien yang masuk rumah sakit dan untuk melakukan monitoring terhadap asuhan gizi yang diberikan sehingga diharapkan dapat mempercepat kesembuhan dan meringankan biaya perawatan di rumah sakit.

\section{BAHAN DAN METODE}

Penelitian ini bersifat analitik eksploratif dengan desain cross sectional. Penelitian dilakukan di Rumah Sakit Dr. Moewardi, Surakarta, Propinsi Jawa Tengah pada bulan Januari-Mei 2005. Subjek penelitian ini adalah pasien yang dirawat inap dengan kriteria berusia $\geq 18$ tahun, tidak dalam keadaan hamil, tidak ber- penyakit gagal fungsi hati atau ginjal, bisa dilakukan pengukuran tinggi badan dan berat badan. Adapun respondennya adalah yang melakukan uji coba penilaian status gizi dengan alat penilaian gizi sederhana (PGS), yaitu perawat/ bidan dengan pendidikan minimal tingkat akademi. Dua puluh orang pasien dan 20 orang perawat dilibatkan pada uji coba tahap pertama, 50 orang pasien dan 50 orang perawat ikut serta pada uji coba tahap kedua yang dipilih dengan menggunakan teknik random sampling.

Variabel terikat adalah status gizi dan variabel bebas adalah metode penilaian status gizi dengan serum albumin dan metode penilaian status gizi dengan alat penilaian gizi sederhana (atau PGS) (Gambar 1). Semua pasien ditentukan status gizinya dengan

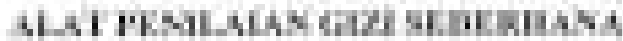

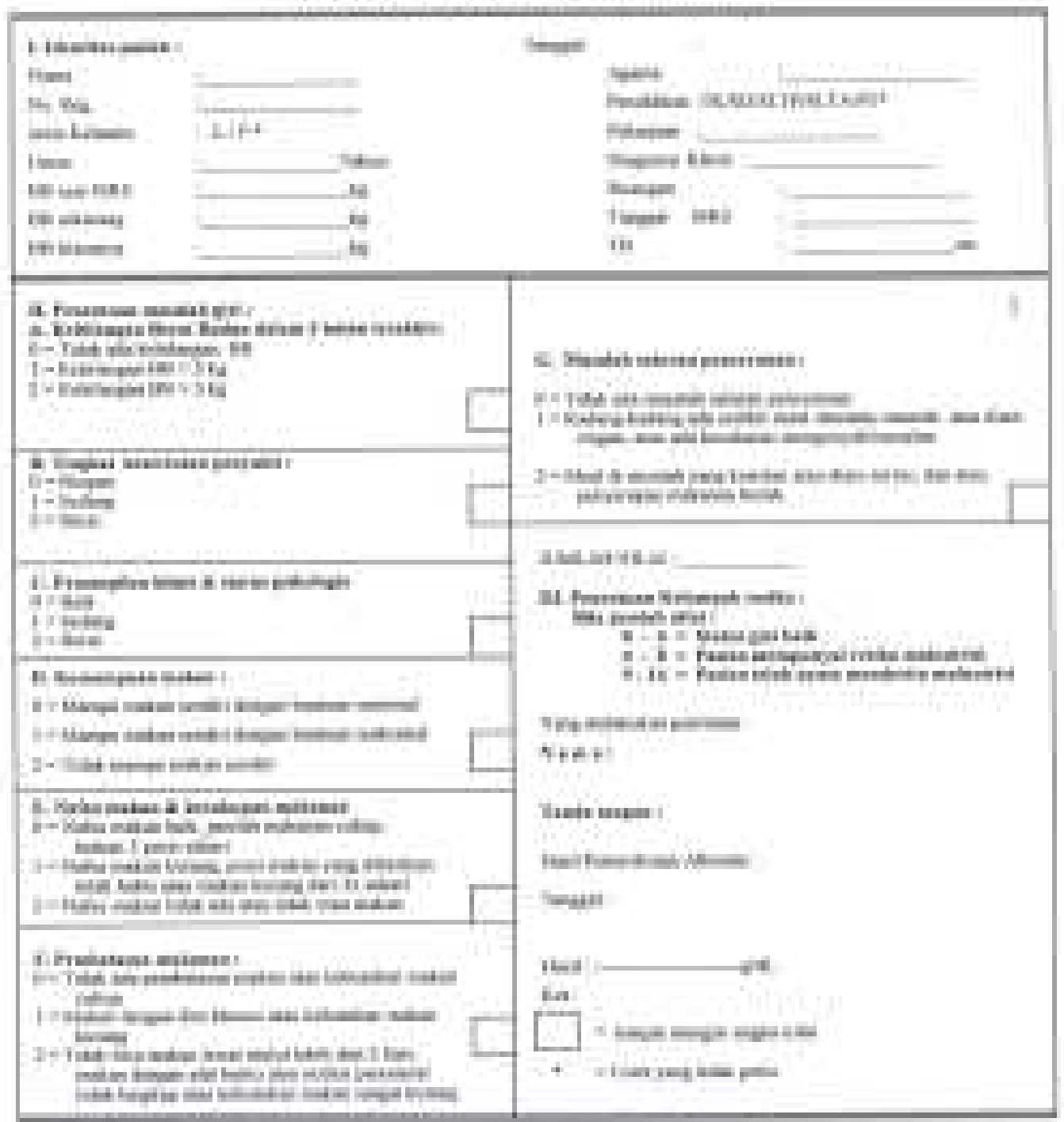

GAMBAR 1. Alat Penilaian Gizi Sederhana (PGS) 
pemeriksaan serum albumin sebagai baku emas. Kelompok risiko ditentukan gizi baik atau tidak ada risiko malnutrisi bila serum albumin $3,5-5,0 \mathrm{~g} / \mathrm{dL}$, berisiko tinggi malnutrisi bila serum albumin $2,8-3,5 \mathrm{~g} /$ $\mathrm{dL}$ dan aktual malnutrisi bila serum albumin $<2,8 \mathrm{~g} / \mathrm{dL}$.

Pada tahap uji coba tahap pertama status gizi 20 orang pasien dinilai oleh 20 orang perawat dengan menggunakan PGS kemudian hasilnya dibandingkan dengan serum albumin. Setelah uji coba tahap pertama PGS diperbaiki kemudian dilakukan lagi uji coba tahap kedua pada 50 orang pasien. Setelah itu dilakukan uji validitas dan reliabilitas dengan membandingkan hasil penilaian PGS dengan hasil serum albumin.

Validitas muka (face validity) dan validitas isi (content validity) dinilai melalui penilaian para pakar. Validitas sewaktu (concurrent validity) dinilai melalui pengukuran sensitivitas, spesifisitas dan likelihood ratio (LR) . Validitas prediktif (predictive validity) dinilai dengan mengukur nilai prediktif positif dan nilai prediktif negatif. Penilaian reliabilitas PGS dilakukan dengan tes homogenitas menggunakan Korelasi Item-Total (ItemTotal Correlation) dan Alpha $(\alpha)$ Cronbach. Stabilitas alat ukur PGS diukur dengan koefisien kesepakatan KAPPA COHEN.

\section{HASIL DAN BAHASAN}

Karakteristik subjek pasien yang mengikuti penelitian ini dapat dilihat pada Tabel 1. Subjek pada penelitian ini terdiri dari kelompok umur 22-40 tahun (68\%). Distribusi jenis kelamin pasien cukup merata, yaitu 27 orang laki-laki (54\%) dan 23 orang perempuan (46\%).

TABEL 1. Karakteristik pasien yang mengikuti kegiatan penelitian

\begin{tabular}{lcc}
\hline \multicolumn{1}{c}{ Variabel } & Frekuensi & Persentase (\%) \\
\hline Kelompok umur & 2 & \\
18-21 tahun & 12 & 4 \\
$22-40$ tahun & 20 & 24 \\
$41-55$ tahun & 16 & 40 \\
$>55$ tahun & 50 & 32 \\
Jumlah & & 100 \\
\hline Jenis kelamin & 27 & \\
Laki-laki & 23 & 54 \\
Perempuan & 50 & 46 \\
Jumlah & & 100 \\
\hline Tingkat pendidikan & 4 & 8 \\
Tidak sekolah & 17 & 34 \\
SD & 8 & 16 \\
SMP & 19 & 38 \\
SMP & 2 & 4 \\
Perguruan Tinggi & 50 & 100 \\
Jumlah & & \\
\hline Kelompok pekerjaan & 22 & 44 \\
Swasta/Dagang & 7 & 14 \\
PNS/Pensiunan & 8 & 16 \\
Tani/Buruh & 11 & 22 \\
Ibu rumah tangga/tidak bekerja & 2 & 4 \\
Lain-lain & 50 & 100 \\
Jumlah & 16 & 32 \\
\hline Ruang rawat inap & 14 & 28 \\
Anggrek & 20 & 400 \\
Mawar & 50 & \\
Melati & & \\
Jumlah & & \\
\hline
\end{tabular}


Pada penelitian ini, penilaian gizi seorang pasien dengan menggunakan PGS dilakukan dua kali oleh perawat yang berbeda, penilaian status gizi yang pertama disebut PGS 1 dan penilaian status gizi kedua disebut PGS 2. Setelah setiap poin isian pada PGS diisi, dilakukan penentuan kelompok risiko berdasarkan jumlah total poin nilai PGS yang didapatkan. Pada penilaian status gizi subjek pasien oleh responden perawat yang pertama dan kedua didapatkan hasil seperti tampak pada Tabel 2.
Tabel 3. Pada penelitian ini reliabilitas alat ukur PGS dinilai dengan melakukan uji homogenitas dengan menggunakan Korelasi Item Total (Item-Total Correlation) dan Alpha $(\alpha)$ Cronbach. Hasil analisis reliabilitas pada penilaian status gizi pertama dan kedua ditampilkan pada Tabel 4.

Untuk mengukur kesepakatan (concordance, agreement) dan reliabilitas (reliability, reproducibility) antara dua pengamat, digunakan koefisien kesepakatan Kappa Cohen. Pada uji coba tahap pertama terhadap

TABEL 2. Distribusi subjek berdasarkan kelompok risiko gizi dari hasil penilaian serum albumin dan alat penilaian gizi sederhana (PGS) oleh responden perawat pertama (PGS 1) dan kedua (PGS 2).

\begin{tabular}{lcccccc}
\hline \multirow{2}{*}{ Kelompok } & \multicolumn{2}{c}{ Serum albumin } & \multicolumn{2}{c}{ PGS 1 } & \multicolumn{2}{c}{ PGS 2 } \\
\cline { 2 - 7 } & $\mathbf{n}$ & $\mathbf{n}$ & $\mathbf{n}$ & $\mathbf{\%}$ & $\mathbf{n}$ & \% \\
\hline Status gizi baik & 37 & 74 & 29 & 58 & 26 & 52 \\
Berisiko tinggi malnutrisi & 10 & 20 & 16 & 32 & 19 & 38 \\
Aktual malnutrisi & 3 & 6 & 5 & 10 & 5 & 10 \\
\hline Total & 50 & 100 & 50 & 100 & 50 & 100 \\
\hline
\end{tabular}

TABEL 3. Hasil uji validitas alat penilaian gizi sederhana oleh responden perawat pertama dan kedua (PGS 1 dan PGS 2) (n=50)

\begin{tabular}{lcc}
\hline \multicolumn{1}{c}{ Uji Validitas } & PGS 1 & PGS 2 \\
\hline Sensitivitas & $92,3 \%$ & $92,3 \%$ \\
Spesifisitas & $75,7 \%$ & $67,57 \%$ \\
Likelihood Ratio (+) & 3,8 & 2,9 \\
Likelihood Ratio (-) & 0,1 & 1,37 \\
Nilai Prediktif (+) & $57,1 \%$ & $50 \%$ \\
Nilai Prediktif (-) & $96,6 \%$ & $96,15 \%$ \\
\hline
\end{tabular}

Validitas sewaktu (concurrent validity) dinilai melalui pengukuran sensitivitas, spesifisitas dan likelihood ratio. Validitas prediktif diukur dengan nilai prediktif positif dan nilai prediktif negatif. Hasil uji validitas pada PGS 1 dan PGS 2 ditampilkan pada
20 orang responden perawat yang menilai status gizi 20 orang responden secara berpasangan, ditemukan k Cohen's antara serum albumin dengan PGS seperti ditampilkan pada Tabel 5.

TABEL 4. Hasil analisis reliabilitas - skala (alpha \& split) alat penilaian gizi sederhana oleh responden perawat pertama dan kedua (PGS 1 dan PGS 2) ( $n=50)$

\begin{tabular}{lcccc}
\hline \multirow{2}{*}{\multicolumn{1}{c}{ Item }} & \multicolumn{2}{c}{ PGS 1 } & \multicolumn{2}{c}{ PGS 2 } \\
\cline { 2 - 5 } & Mean & SD & Mean & SD \\
\hline Perubahan berat badan & 0,80 & 0,88 & 0,82 & 0,85 \\
Tingkat keseriusan penyakit & 1,08 & 0,75 & 1,00 & 0,73 \\
Penampilan klinis dan status psikologis & 0,64 & 0,60 & 0,58 & 0,57 \\
Kemampuan makan & 0,16 & 0,37 & 0,18 & 0,44 \\
Nafsu makan dan kecukupan makanan & 0,38 & 0,53 & 0,42 & 0,54 \\
Pembatasan makan & 0,30 & 0,46 & 0,30 & 0,46 \\
Masalah saluran pencernaan & 0,38 & 0,53 & 0,44 & 0,58 \\
Alpha & \multicolumn{2}{c}{0,80} & \multicolumn{3}{c}{0,80} \\
\hline
\end{tabular}


TABEL 5. Hasil analisis koefisien kesepakatan Kappa Cohen pada uji coba alat penilaian gizi sederhana (PGS) tahap pertama $(n=20)$

\begin{tabular}{cccc}
\hline Variabel 1 & Variabef 2 & $\begin{array}{c}k \text { Cohen's kelompok risiko } \\
\text { awal }\end{array}$ & $\begin{array}{c}k \text { Cohen's kelompok risiko } \\
\text { baru }\end{array}$ \\
\hline PGS 1 & PGS 2 & 0,79 & 0,92 \\
\hline
\end{tabular}

Dengan format PGS yang telah diperbaharui, dilakukan lagi uji coba tahap kedua dengan hasil $\mathrm{k}$ Cohen's antara serum albumin dengan penilaian PGS seperti ditampilkan pada Tabel 6.
Sampai saat ini belum ada kesamaan atau konsensus pada literatur-literatur ilmiah mengenai variabel-variabel atau kombinasi terbaik dari variabel tersebut untuk diaplikasikan atau digunakan guna

TABEL 6. Hasil analisis koefisien kesepakatan Kappa Cohen pada uji coba alat penilaian gizi sederhana (PGS) tahap kedua $(n=50)$

\begin{tabular}{cccc}
\hline Variabel 1 & Variabel 2 & $\begin{array}{c}\text { k Cohen's kelompok } \\
\text { risiko awal }\end{array}$ & $\begin{array}{c}\text { k Cohen's kelompok } \\
\text { risiko baru }\end{array}$ \\
\hline PGS 1 & PGS 2 & 0,79 & 0,92 \\
\hline
\end{tabular}

Pada penelitian ini juga dilihat waktu yang diperlukan oleh perawat untuk mengisi komponenkomponen penilaian dan menentukan status gizi. Dua puluh responden dipilih secara acak kemudian dicatat lama waktu yang diperlukan oleh perawat dalam mengisi poin komponen-komponen penilaian dan menentukan status gizi pasien. Rata-rata (SD) waktu yang diperlukan oleh perawat dalam mengisi poin komponen-komponen penilaian dan menentukan status gizi pasien sebesar $5,1(1,9)$ menit dengan waktu minimal 3 menit dan maksimal 9 menit, dengan nilai tengah 5 menit.

Metode yang sering digunakan untuk menilai status gizi secara langsung adalah pengukuran komponen-komponen tubuh, seperti tinggi badan, berat badan, tebal lipatan lemak bawah kulit, lingkar perut, dan lain-lain. Cara lain adalah dengan tes laboratorium seperti pemeriksaan serum albumin, prealbumin, transferin, status imun, dan lain-lain $(1,6,7)$. Jangkauan penilaian dengan metode ini sangat luas dan metode ini juga dipengaruhi oleh sifat, tingkat keseriusan dan lamanya berbagai penyakit. Variabel-variabel penilaian ini seiring waktu hanya berupa gambaran sekilas saja dan karena itu tidak mampu memprediksi perkembangan selanjutnya $(6,8)$. Metode lain untuk menentukan status gizi ini adalah gabungan dari berbagai macam variabel klinis yang menjelaskan alur berkelanjutan dari kekurangan gizi, seperti observasi klinis misalnya nafsu makan atau penampilan klinis. Salah satu variabel ini merupakan variabel Subjective Global Assessment (SGA) dan Nursing Nutritional Screening Form (NNSF) (6). menentukan status gizi $(9,10,11)$. Reilly et al (12) mengembangkan format pengujian status gizi yaitu nilai risiko gizi yang didasarkan pada komponen kehilangan berat badan, Indeks Massa Tubuh, faktor stres dan jumlah makanan yang dikonsumsi. De Kruif \& Vos (6) juga mengembangkan format penilaian status gizi yang didasarkan pada komponen perubahan berat badan, penampakan klinis, nafsu makan, konsumsi makan dan tingkat keseriusan penyakit, perlakuan dan intervensi. Pengujian format ini melibatkan pasangan perawat, dokter klinik dan ahli gizi dengan standar emas yang digunakan pada penelitian ini adalah evaluasi dan pendapat para ahli gizi.

Berdasarkan indikator status gizi yang paling penting yaitu perubahan berat badan, jumlah makanan yang dikonsumsi dan sifat-sifat penyakit, perawatan atau intervensi (6), format PGS dikembangkan dengan melibatkan perawat, dokter klinik dan ahli gizi. Komponen-komponen yang ada pada format PGS merupakan komponen-komponen yang telah digunakan untuk menilai status gizi pada beberapa penelitian sebelumnya $(6,13)$.

Pada mulanya format PGS terdiri dari komponenkomponen sebagai berikut: A) Penentuan keadaan gizi yang terdiri dari pertanyaan: Indeks Massa Tubuh, perubahan berat badan, penampilan klinis dan kesadaran serta tingkat keseriusan penyakit; dan B) Konsumsi makanan, yang terdiri dari komponen pertanyaan: nafsu makan dan kecukupan makanan, kemampuan makan, pembatasan makan serta masalah saluran pencernaan. Jika semua komponen 
diberi nilai $A$, maka pasien dianggap status gizinya baik dan tidak mempunyai risiko malnutrisi. Jika beberapa dari komponen tersebut diberi nilai B atau C maka pasien secara potensial memiliki risiko kekurangan gizi.

Setelah divalidasi oleh para pakar dan dengan melibatkan ahli gizi, dokter klinik dan perawat, format PGS tersebut dianggap cukup rumit dan masih ada komponen-komponen yang bisa lebih disederhanakan lagi. Komponen Indeks Massa Tubuh dihilangkan karena informasi gizi masa lalu dianggap sudah diperoleh dari komponen konsumsi makanan. Setiap item pada komponen perubahan berat badan disederhanakan untuk mempermudah pengisian. Teknik penilaian juga diganti dari pengelompokkan komponen pada kelompok nilai $\mathrm{A}, \mathrm{B}$ dan $\mathrm{C}$, menjadi kelompok nilai 1, 2, dan 3 dengan penentuan kelompok risiko gizi berdasarkan jumlah total nilai. Kemudian dilakukan perbaikan terhadap format PGS.

Format PGS yang telah diperbaharui terdiri dari komponen-komponen kehilangan berat badan dalam 3 bulan terakhir, tingkat keseriusan penyakit, penampilan klinis dan status psikologis, kemampuan makan, nafsu makan dan kecukupan makanan, pembatasan makanan serta masalah saluran pencernaan. Semua nilai pada setiap komponen dijumlahkan kemudian hasil total nilai yang didapat dimasukkan dalam kelompok risiko yang sudah ditentukan. Pada uji coba tahap pertama, nilai untuk penentuan kelompok risiko dibagi menjadi:

$$
\begin{array}{ll}
0-1 & =\text { Status gizi baik } \\
2-7 & =\text { Pasien berisiko malnutrisi } \\
8-14 & =\text { Aktual malnutrisi }
\end{array}
$$

Setelah dilakukan uji coba alat PGS untuk menilai status gizi terhadap 20 orang subjek pasien oleh 20 orang pasangan responden perawat, ternyata dengan pembagian kelompok risiko tersebut didapat-kan kesepakatan k Cohen's antara PGS dengan serum albumin sebagai gold standard sedang $(\mathrm{k}=0,302)$ pada penilaian PGS yang pertama dan kesepakatan buruk $(\mathrm{k}=0,179)$ pada penilaian PGS yang kedua dibandingkan dengan serum albumin. Menurut Landis \& Koch (14), kesepakatan k Cohen's dikatakan cukup baik bila $k \geq 0,4(6,15)$.

Tahap selanjutnya berdasarkan hasil uji coba dan masukan para pakar, dilakukan perubahan pada kelompok nilai pada penentuan kelompok risiko menjadi sebagai berikut :

$$
\begin{array}{ll}
0-3 & =\text { Status gizi baik } \\
4-8 & =\text { Berisiko malnutrisi } \\
9-14 & =\text { Aktual malnutrisi }
\end{array}
$$

Dengan menggunakan penentuan kelompok risiko yang baru, ternyata pada uji coba tahap pertama ini, $\mathrm{k}$ Cohen's untuk penilaian status gizi hasil PGS pertama dan PGS kedua dibandingkan dengan status gizi hasil penilaian serum albumin kesepakatannya menjadi baik ( $k=0,641)$ pada PGS pertama dan cukup baik ( $k$ $=0,561$ ) pada PGS kedua.

Sensitivitas PGS pertama dibandingkan dengan serum albumin adalah $92,3 \%$, artinya kemampuan PGS pertama dalam memberikan hasil malnutrisi jika digunakan untuk mengukur pasien yang memang malnutrisi menurut albumin adalah sangat tinggi. Nilai yang sama juga didapatkan pada ukuran sensitivitas PGS kedua dengan baku emas serum albumin dengan sensitivitas $=92,3 \%$. Sensitivitas PGS tidak berubah walaupun digunakan oleh perawat yang berbeda untuk menilai status gizi pasien yang sama.

Spesifisitas PGS pertama adalah $75,7 \%$ dan spesifisitas PGS kedua $67,6 \%$, artinya kemampuan PGS dalam memberikan hasil status gizi baik pada pasien yang memang berstatus gizi baik menurut serum albumin masih rendah. Dengan kata lain, masih banyak pasien yang dinilai malnutrisi oleh PGS meskipun dengan pemeriksaan serum albumin pasien tersebut dinyatakan berstatus gizi baik.

Nilai sensitivitas dan spesifisitas tercermin dalam likelihood ratio (LR). LR(+) PGS pertama 3,8 berarti penggunaan PGS ini akan meningkatkan nilai post test probability dari malnutrisi, sedangkan terhadap status gizi baik pengaruh PGS pertama terhadap post test probability rendah karena $L R(-)=0,1$. Untuk PGS kedua nilai $\operatorname{LR}(+)$ 2,9 jadi masih meningkatkan nilai post test probability malnutrisi. Sedangkan pengaruh PGS kedua terhadap post test probability status gizi baik hampir tidak ada dengan $\operatorname{LR}(-)=1,37$.

Pada penelitian yang membandingkan beberapa metode penilaian status gizi pada pasien rawat inap yaitu Chandra Screening Tool, The Mini Nutritional Assessment (MNA) dan The Nutrition Screening Initiative (NSI) ditemukan sensitivitas masing-masing alat tersebut berturut-turut adalah $32,3 \%, 54,4 \%$ dan $56,7 \%$. Spesifisitas ketiga alat tersebut berturut - turut adalah $85,5 \%, 61,3 \%$ dan $69,4 \%$ (4). The Mini Nutritional Assessment (MNA), merupakan alat ukur status gizi yang telah digunakan untuk orang dewasa yang dirawat maupun tidak dirawat dengan sensitivitas yang juga tinggi (96\%). Di rumah sakit, nilai MNA berkorelasi dengan besarnya biaya rawat inap, skor MNA yang rendah berhubungan erat dengan lebih lama dan lebih mahalnya biaya perawatan yang dikeluarkan (16). Sedangkan The Subjective Global Assessment (SGA) 
menunjukkan sensitivitas $78 \%$ dan $70 \%$ spesifisitasnya dalam memprediksi terjadinya infeksi pada pasien pasien bedah (10).

Validitas prediktif pada penelitian ini dinilai dengan ukuran nilai prediktif positif dan prediktif negatif. Pada penilaian PGS pertama didapatkan nilai prediktif positifnya adalah $57,1 \%$, tidak berbeda jauh dengan nilai prediktif positif PGS kedua yaitu 50\%. Hal ini berarti, probabilitas pasien rawat inap yang dikategorikan malnutrisi oleh pada penilaian PGS adalah memang benar-benar malnutrisi menurut pemeriksaan serum albumin masih cukup rendah, masih terdapat banyak pasien yang dinilai malnutrisi oleh PGS ternyata dinyatakan status gizi baik menurut pemeriksaan serum albumin. Nilai prediktif negatif PGS pertama $=96,6 \%$, hampir sama dengan nilai prediktif negatif pada PGS kedua yaitu $96,15 \%$. Hal ini berarti probabilitas pasien rawat inap yang dinilai berstatus gizi baik menurut PGS, benar-benar dikategorikan status gizi baik menurut pemeriksaan serum albumin. Dapat dikatakan hampir semua pasien rawat inap yang dinilai berstatus gizi baik oleh PGS pertama dan PGS kedua memang berstatus gizi baik menurut hasil pemeriksaan serum albumin.

Aspek konsistensi internal pada penelitian ini dinilai dengan teknik Korelasi Item Total dan Reliabilitas Belah Paroh. Korelasi item total merupakan tes homogenitas PGS dengan cara mengkorelasikan komponenkomponen secara individual dalam PGS dengan PGS secara keseluruhan setelah mengurangi komponen dimaksud. Dari tujuh komponen PGS, yaitu: (1) Perubahan berat badan, (2) Tingkat keseriusan penyakit, (3) Nafsu makan dan kecukupan makanan, (4) Kemampuan makan, (5) Penampilan klinis dan status psikologis, (6) Pembatasan makan serta (7) Masalah saluran pencernaan, baik pada PGS pertama maupun PGS kedua semua komponen mempunyai nilai korelasi item total lebih dari 0,20 kecuali komponen "kemampuan makan" yang mempunyai korelasi item total 0,16 pada $P G S$ pertama dan 0,18 pada $P G S$ kedua. Secara umum dapatlah dikatakan bahwa masing-masing komponen yang terdapat pada PGS berkorelasi kuat dengan PGS secara keseluruhan. Korelasi paling tinggi terdapat pada komponen "tingkat keseriusan penyakit" yaitu 1,08 pada PGS pertama dan 1,0 pada PGS kedua.

Reliabilitas belah paroh menggunakan metode Alpha Cronbach yang dapat digunakan untuk komponen-komponen yang mempunyai lebih dari dua jawaban telah dilakukan. Hasil yang diperoleh menunjukkan bahwa baik PGS pertama maupun PGS kedua memiliki konsistensi internal alat ukur yang baik karena Alpha Cronbach PGS pertama dan kedua adalah 0,80 .

Tingkat kesepakatan para perawat dikategorikan baik dalam mengukur pasien yang sama untuk komponen "kehilangan berat badan dalam tiga bulan terakhir" ( $k=0,779)$, komponen "tingkat keseriusan penyakit" $(k=0,627)$, komponen "penampilan klinis dan status psikologis" ( $k=0,596)$, komponen "nafsu makan dan kecukupan makanan" ( $\mathrm{k}=0,753)$ dan komponen "masalah saluran pencernaan" ( $\mathrm{k}=0,797)$. Kesepakatan dikategorikan sangat baik pada komponen "pembatasan makanan" ( $k=0,810)$, sedangkan untuk komponen "kemampuan makan" nilai k Cohen's tidak dapat dihitung karena tidak ditemukan poin 2 pada PGS pertama sehingga tabel simetris tidak dapat dibuat.

Kesepakatan dikategorikan sangat baik $(\mathrm{k}=0,916)$ ditunjukkan pada penilaian status gizi pasien yang sama dengan pengukur berbeda yang menggunakan PGS yang sama pada periode uji coba tahap pertama dan sangat baik $(k=0,859)$ pada uji coba tahap kedua. Tingginya nilai kesepakatan ini menjelaskan bahwa alat ukur status gizi PGS mempunyai stabilitas yang tinggi. PGS ternyata mempunyai stabilitas yang sangat baik pada saat digunakan oleh individu yang berbeda.

Pasien rawat inap $(n=50)$ yang telah dinilai status gizinya oleh berbagai metode penilaian status gizi memberikan hasil yang cukup bervariasi. Pasien dengan gizi baik atau tidak mempunyai risiko malnutrisi ditemukan pada 37 pasien (74\%) dengan serum albumin, 29 (58\%) dengan PGS pertama, 26 (52\%) dengan PGS kedua. Pasien yang berisiko kekurangan gizi hingga aktual malnutrisi ditemukan 13 pasien $(26 \%)$ dengan serum albumin, 21 pasien (42\%) dengan PGS pertama, 24 pasien (48\%) dengan PGS kedua. Hasil penilaian status gizi dengan berbagai metode penilaian status gizi ini membuktikan masih tingginya angka malnutrisi pada pasien rawat inap yaitu lebih dari $20 \%$. Penemuan ini mendukung penelitian lain mengenai masih tingginya kasus malnutrisi pada pasien rawat inap dimana masih ditemukan $20-60 \%$ pasien rawat inap menderita malnutrisi atau berada dalam ancaman kekurangan gizi $(1,2,3,4,10,17)$.

PGS ini sendiri diharapkan dapat menjadi salah satu alternatif yang dapat digunakan sebagai alat screening gizi bagi pasien yang dirawat di rumah sakit. Pertimbangan yang diajukan oleh peneliti adalah bahwa screening gizi dengan menggunakan PGS hampir tidak memerlukan biaya sama sekali, hanya diperlukan selembar format PGS. Waktu rata-rata yang diperlukan untuk melakukan screening juga sangat singkat yaitu 5 menit untuk setiap pasien setiap kali screening dilakukan. Keuntungan lain adalah PGS tidak bersifat 
invasif dan tidak merugikan pasien baik dari aspek finansial maupun risiko yang ditimbulkan.

\section{KESIMPULAN DAN SARAN}

Alat Penilaian Gizi Sederhana (PGS) dapat digunakan untuk menilai status gizi pasien rawat inap di rumah sakit dengan sensitivitas dan reliabilitas tinggi, cepat dan cukup aman bagi pasien. PGS dapat disarankan untuk digunakan dalam menilai status gizi pasien rawat inap di rumah sakit.

\section{RUJUKAN}

1. Mc Whirter JP, Pennington CR. Incidence and Recognition of Malnutrition in Hospital. BMJ 1994;308:945- 8.

2. Campbell ES, Avenell A, Walker EA. Assessment of Nutritional Status in Hospital in-Patients. QJ Med 2001;95:83-7.

3. Bristrian BR, Blacburn GL, Hallowell E, Heddle R. Protein Status of General Surgical Patients. JAMA 1974;230:858-60.

4. zad N, Murphy J, Amos S, Toppan J. Nutrition Survey in an Elderly Population Following Admission to A Tertiary Care Hospital. CMAJ 1999;161(5):511-5.

5. Nutrition Screening Initiative (NSI). Malnutrition. Among the Elderly: Expensive and Preventable. Am Fam Physician 2004. Available from Http:// www.AAFP.

6. De Kruif J Th C and Vos A. An Algorithm for the Clinical Assessment of Nutritional Status in Hospitalized Patients. Br J Nutr 2003;90:829-36.

7. Gibson RS. Principles of Nutritional Assessment. New York: Oxford University Press; 1990.
8. Supariasa NDI, Bakri B, Fajar I. Penilaian Status Gizi. Jakarta: Penerbit Buku Kedokteran EGC; 2002.

9. Collins JP, Carthy Mc ID, \& Hill GL. Assessment of Protein Nutrition in Surgical Patients-The Value of Anthropometrics. Am J Clin 1979;32:1527-30.

10. Corish AC. Pre-Operative Nutritional Assessment. Proc Nutr Soc 1999;58:821-9.

11. Stratton JR, Hackston A, Longmore D, Dixon R, Price S, Stroud M, King C, Elia M. Malnutrition in Hospital Outpatients and Inpatients : Prevalence, Concurrent Validity and Ease of Use of The 'Malnutrition Universal Screening Tool' ('MUST') for Adults. BMJ 2004;92:799-808.

12. Reilly HM, Martineau JK, Moran A \& Kennedy H. Nutritional Screening. Evaluation and Implementation of A Simple Nutrition Risk Score. Clin Nutr 1995;14:269-73.

13. Nestle Nutrition Services. Mini Nutritional Assessment (MNA). @Nestle 1994, Revision 1998. N67200 12/99 10M

14. Landis RJ and Koch GG. The Measurement of Observer Agreement for Categorical data. Biometrics 1977;33:159-74.

15. Murti B. Penerapan Metode Statistik Non Parametrik dalam IImu-IImu Kesehatan. Jakarta: PT Gramedia Pustaka Utama; 1996.

16. Lauque S, Nourhashemi F, Vellas B. Nutritional Evaluation Tools in The Elderly. Z. Gerontol Geriat 1999;32(7):S45-S54.

17. British Dietetic Association. Nutrition Screening \& Assessment: Does it Really Work in Hospital? Affective Practice Bulletin. Issue 33 May 2003 